DOI: 10.33295/1992-576X-2019-4-48

\title{
К.С. Печковський ${ }^{1}$ О.Ф. Несин ${ }^{1}$, І.М. Печковська², Т.О. Тімохіна ${ }^{1}$, О.Г. Шкредъ Використання Тантум Верде ${ }^{\circledR}$ в лікуванні хронічної механічної травми слизової оболонки порожнини рота
}

\author{
${ }^{1}$ Національний медичний університет імені О.О.Богомольця, м. Київ, Україна \\ 2Приватний вищий навчальний заклад «Київський медичний університет», м. Київ, Україна
}

\begin{abstract}
Актуальність. У лікуванні ерозивно-виразкових уражень слизової оболонки порожнини рота, зумовлених хронічною механічною травмою, обґрунтованим є застосування засобів комплексної дії, які б справляли місцевий протизапальний вплив, ослаблювали біль у слизовій оболонці, мали б антисептичні і протимікробні властивості. Одним із них $є$ Тантум Верде ${ }^{\circledR}-$ місцевий нестероїдний протизапальний препарат на основі бензидаміну гідрохлориду.

Метою роботи була оцінка ефективності використання препарату «Тантум Верде » у місцевому лікуванні ерозивно-виразкових уражень слизової оболонки порожнини рота, зумовлених хронічною механічною травмою.

Результати досліджень. Проведене лікування 30 хворих, віком 18-58 років, із ерозивно-виразковими ураженнями слизової оболонки порожнини рота, викликаними хронічною механічною травмою ортопедичними конструкціями чи ортодонтичними апаратами. У 6 пацієнтів із знімними протезами відмічали також розростання слизової оболонки у ділянках контакту з краями протезу. У 15 хворих дослідної групи був додатково застосований препарат «Тантум Верде ${ }^{\circledR}$ ».

Зникнення чи значне зменшення клінічних ознак ерозивно-виразкових уражень від механічної травми ортопедичними конструкціями чи ортодонтичними апаратами відбулося на 1-1,5 доби раніше у хворих дослідної групи. Відмічено позитивний вплив Тантум Верде ${ }^{\circledR}$ на тамування болю, гігієнічний стан, поліпшення трофіки тканин та загоєння ділянок слизової оболонки після хірургічного видалення протезних гранульом.

Висновки. Препарат «Тантум Верде ${ }^{\circledR}$ е ефективно тамує біль та прискорює зникнення ознак запалення, покращує трофіку, прискорює загоєння та епітелізацію дефектів у хворих з ерозивно-виразковими ураженнями слизової оболонки порожнини рота, що виникають після хронічної механічної травми зубними протезами та незнімними ортодонтичними апаратами. Він ослаблює реактивну запальну реакцію тканин на хірургічне втручання після видалення протезних гранульом, покращує гігієну, прискорює загоєння і зняття швів на 1-1,5 доби.
\end{abstract}

Ключові слова: «Тантум Верде ${ }^{\circledR}$, хронічна механічна травма слизової оболонки порожнини рота, ерозивно-виразкові ураження, місцеве лікування.

Б іль - найчастіший симптом захворювань чи станів людини, який змушує звертатися до лікаря. Він є однією зі складових запальної реакції тканин.

У порожнині рота, в різних ділянках слизової оболонки, біль чинить особливий вплив, заважаючи повноцінно розмовляти, приймати їжу, пити. Навіть незначне ураження, всього одна-єдина афта при хронічному рецидивному афтозному стоматиті може суттєво пригнічувати психологічний стан пацієнта.

Деякі декубітальні виразково-некротичні ураження супроводжуються дуже сильним невралгієподібним болем.

Болісність м'яких тканин порожнини рота при ерозивно-виразкових ураженнях, що довго не гояться, значно погіршує якість життя, призводить до порушення загального стану хворого: розвивається схуднення, анемія, дизбіоз кишківника.

Для патогенетичного та симптоматичного лікування таких уражень обгрунтованим є застосування засобів комплексної дії, які б мали місцевий протизапальний вплив та ослаблювали біль у слизовій оболонці, мали б антисептичні і протимікробні властивості [10].

Такими властивостями володіє препарат Тантум Верде ${ }^{\circledR}$ (компанія Angelini, Італія) - місцевий нестероїдний протизапальний препарат на основі бензидаміну гідрохлориду, що активно діє на ланки патогенезу та симптоми запалення у слизовій оболонці порожнини рота, носо- та ротоглотці і тканинах пародонта [1-8, 11-19, 21, 23, 25]. Він справляє протизапальну, протинабрякову, анестезуючу та антибактеріальну дію [20, 22, 24, 26$].$
Різні форми випуску (розчин, спрей і льодяники) надають можливість використовувати препарат у лікуванні ерозивно-виразкових захворювань та уражень у різних ділянках слизової оболонки порожнини рота.

Метою дослідження було: оцінити ефективність використання препарату Тантум Верде ${ }^{\circledR}$ у місцевому лікуванні ерозивно-виразкових уражень слизової оболонки порожнини рота, зумовлених хронічною механічною травмою.

\section{Матеріали та методи дослідження}

У дослідженні приймали участь 30 хворих із механічними травматичними ураженнями слизової оболонки порожнини рота, віком 18-58 років, яким було проведено клініко-лабораторне обстеження. Усі хворі мали декубітальні ерозивно-виразкові ураження, викликані хронічною травмою незнімними чи знімними ортопедичними конструкціями, ортодонтичними апаратами.

За наявності мостовидних конструкцій травма виникала у результаті переламу чи від'єднання проміжної частини від однієї з опорних коронок, і тиску їі на ясенний край. При використанні знімних пластинкових протезів травма виникала при несвоєчасному звертанні пацієнтів для їх корекції. У 6 пацієнтів, окрім ерозивно-виразкових уражень, відмічали проліферацію (розростання) слизової оболонки по краях ділянки тривалого контакту механічного травмуючого чинника із СОПР. Пролежневі ерозивно-виразкові ураження в результаті використання незнімної ортодонтичної апаратури виникали від тиску брекетів на слизову оболонку губ та щік. Термін існування механічної травми у всіх випадках був 1-3 місяці. 
Усі хворі були розподілені на дві групи, дослідну та порівняння, по 15 пацієнтів у кожній. Розподіл хворих у групах за статтю та віком був аналогічним. Усі пацієнти дали добровільну поінформовану згоду на участь у дослідженні. Комплексне лікування хворих проводили згідно з існуючими протоколами.

Основну частину лікування хворим порівнюваних груп проводили за однаковою схемою: антисептична обробка порожнини рота і ділянки ураження, некректомія, місцева протизапальна терапія, стимуляція епітелізації. В дослідній групі використовували Тантум Верде ${ }^{\circledR}$ у вигляді 0,15 \% спрею та розчину, розраховуючи на його знеболюючий, протизапальний, протинабряковий та антисептичний ефекти.

Лікування та спостереження за хворими обох порівнюваних груп проводили протягом 8-12 діб - до повного загоєння та епітелізації ерозивно-виразкових уражень.

Ефективність лікування хворих визначали за динамікою зменшення-зникнення больових відчуттів, за допомогою проби Шиллера-Писарєва та за динамікою загоєння - швидкості зменшення площі ранової поверхні. Статистичну обробку результатів дослідження проводили з використанням критерію Ст'юдента [9].

\section{Результати досліджень.}

Пацієнтам обох груп у перше відвідування усували вплив хронічної механічної травми: проводили видалення зруйнованих мостовидних ортопедичних конструкцій (по 7 хворих), корекцію повних чи часткових знімних протезів (по 5 пацієнтів), ізоляцію слизової оболонки губ та щік від контакту з брекет-системою (по 3 хворих).

Антисептичну обробку порожнини рота і декубітальних уражень проводили за допомогою ротових ванночок 0,02 \% розчином калію перманганату.

Для визначення знеболюючого ефекту препарату Тантум Верде ${ }^{\circledR}$ пацієнтам дослідної групи ділянки ураження слизової оболонки обробляли спреєм Тантум Верде ${ }^{\circledR}$. Хворим групи порівняння знеболення не проводили.

Результати знеболення ділянок ураження спреєм Тантум Верде ${ }^{\circledR}$ після усунення хронічної механічної травми наведені у таблиці.

Таким чином, біль у ділянках уражень зменшився у 5 (33,3 \%) хворих дослідної групи, з них: у 1 (6,7 \%) пацієнта за рахунок послаблення болю значної сили, у $3(20,0$ \%) пацієнтів - послаблення помірного болю і у $1(6,7 \%)$ пацієнта зі слабким болем - за рахунок його зникнення.

Видалення нашарувань з поверхні ерозивно-виразкових уражень хворим обох груп проводили ватяними кульками, просоченими $0,5-1,0$ \% розчином натрію гідрокарбонату з подальшим змиванням 1,5 \% розчином водню пероксиду,після чого на ерозивно-виразкові ураження накладали ватяні полоски, просочені розчином настоянки календули (з розрахунку 3 мл настоянки на склянку води) по 10хв. Пацієнтам дослідної групи додатково обробляли ділянки декубітальних уражень $0,15 \%$ спреєм Тантум Верде ${ }^{\circledR}$.

Між відвідуваннями пацієнти дослідної групи робили вдома ротові ванночки $0,15 \%$ розчином Тантум Верде ${ }^{\circledR} 3-4$ рази на день.

В процесі лікування виявилося, що зникнення чи значне зменшення видимих клінічних ознак запалення (біль, кровоточивість, набряк, гіперемія слизової оболонки) відбулося швидше у хворих дослідної групи, ніж у пацієнтів групи порівняння (в середньому через 6 і 7 діб відповідно). Повне ж загоєння та епітелізація дефектів відбулися пізніше у пацієнтів обох порівнюваних груп. Залежно від площі ерозивно-виразкових уражень, повна епітелізація дефектів СОПР відмічена у строки 8-12 діб, проте у хворих дослідної групи клінічно видиме зникнення ознак запалення та загоєння відбулися в середньому на 1-1,5 доби раніше.

Вважаємо, що певне прискорення епітелізації ерозивно-виразкових уражень відбувалося за рахунок протизапального, антибактеріального та анестезуючого впливів препарату Тантум Верде ${ }^{\circledR}$, що, за сукупністю дії, створювало оптимальні умови для загоєння тканин слизової оболонки порожнини рота. Місцево-анестезуючий ефект Тантум Верде ${ }^{\circledR}$ сприяв також поліпшенню трофіки тканин за рахунок блокування нервових закінчень у ділянці ураження.

Клінічні дані підтверджувалися більш швидкою (на 1-1,5 доби раніше)

нормалізацією проби Шиллера-Писарєва у хворих дослідної групи, ніж у пацієнтів групи порівняння. Однак, проба Шиллера-Писарєва у більшості хворих обох груп (в 10 хворих - 66,7 \% дослідної та у 13 пацієнтів - 86,7 \% групи порівняння) залишалася слабкопозитивною ще протягом 2-3діб після повного клінічно видимого загоєння.

По 3 хворих з кожної клінічної групи мали розростання (проліферацію) слизової оболонки, що утворилися у результаті хронічного травмування її краями повних знімних протезів. Пацієнтам кожної клінічної групи було проведено по 6 хірургічних втручань по видаленню протезних гранульом, що утворилися по обидва боки (вестибулярного та піднебінного чи язикового) беззубого альвеолярного відростка. Вплив Тантум Верде ${ }^{\circledR}$ на м'які тканини після хірургічного видалення розростань слизової оболонки (протезної гранульоми) вивчали за динамікою зменшення-зникнення больових відчуттів в перші три доби після втручання, термінами загоєння м'яких тканин та стану швів, зважаючи на те, що крім протинабрякової і протизапальної дії бензидамін блокує розмноження мікроорганізмів (грибів, бактерій, вірусів)

Вплив спрею Тантум Верде ${ }^{\circledR}$ на біль в уділянках ерозивно-виразкових уражень

\begin{tabular}{||l|c|c|c|c||}
\hline \multirow{2}{*}{ Група хворих } & \multicolumn{3}{|c|}{ Біль } \\
\cline { 2 - 5 } & Відсутній & Слабкий & Помірний & Значний \\
\hline \multicolumn{5}{|c|}{ Дослідна $(\mathrm{n}=15)$} \\
\hline до обробки ТВ & $2(13,3 \%)$ & $3(20,0 \%)$ & $7(46,7 \%)$ & $2(13,3 \%)$ \\
\hline через 2 хв. після обробки & $3(20,0 \%)$ & $5(33,3 \%)$ & $5(33,3 \%)$ & $4(26,7 \%)$ \\
\hline \multicolumn{7}{|c|}{ Порівняння (n=15) } \\
\hline обробка ТВ не проводилась
\end{tabular}


і пригнічуе ї ріст [21, 23, 25], що особливо важливо в перші дні після операції, коли повноцінна гігієна післяопераційної ділянки є утрудненою.

Хворим дослідної групи прооперовану ділянку обробляли спреєм Тантум Верде ${ }^{\circledR}$. Вдома самостійно гігієнічну обробку післяопераційної ділянки проводили: пацієнти групи порівняння за допомогою ротових ванночок 0,02\% розчином калію перманганату по 3 рази на день; хворі дослідної групи - крім цього застосовували 0,15 \% розчин Тантум Верде ${ }^{\circledR} 3-4$ рази на день. Ці заходи проводили щодня протягом 7-9 діб - до зняття швів.

Хворі обох груп після операції протягом перших 3 діб відмічали незначні больові відчуття, що не спонукали їх приймати внутрішньо знеболювальні препарати. Проте, пацієнти дослідної групи після обробки уражень $0,15 \%$ розчином Тантум Верде ${ }^{\circledR}$ відчували себе більш комфортно.

Об'єктивно: на 3-ю добу після операції у пацієнтів обох груп залишався незначний набряк у ділянках втручання, шви були збережені з незначною кількістю нашарувань нальоту. Починаючи з п'ятої доби на швах хворих групи порівняння було відмічено більшу кількість нальоту. На сьому добу ця різниця збільшилася, що потребувало більших зусиль для нормалізації гігієнічного стану післяопераційної ділянки.

На 7-му добу після операції у хворих дослідної та на 7-9 добу у пацієнтів групи порівняння післяопераційні ділянки були, в основному, епітелізовані. Окремі шви були відсутні у хворих обох груп. У цих місцях зберігалися незначний набряк та гіперемія м'яких тканин.

Отримані результати показали позитивний вплив Тантум Верде ${ }^{\circledR}$ на тамування болю, гігієнічний стан швів та загоєння ділянок слизової оболонки після хірургічного вилалення протезних гранульом.

Пролежневі ерозивно-виразкові ураження, що виникали в результаті тиску брекетів на слизову оболонку губ та щік, були діагностовані у 6 хворих (по 3 пацієнти в кожній клінічній групі). Основною задачею - етіологічним лікуванням- вважали відсторонення (ізоляцію) травмуючого чинника від контакту з травмованими м'якими тканинами. Ізоляцію слизової оболонки губ та щік здійснювали за допомогою ортодонтичного воску або стерильних марлевих серветок. Лікування ерозивно-виразкових уражень у проекції травмуючого чинника здійснювали за схемою лікування декубітальних уражень, викликаних конструкціями протезів (див. вище).

У хворих дослідної групи, яким для обробки ерозивно-виразкових уражень застосовували $0,15 \%$ спрей та розчин Тантум Верде ${ }^{\circledR}$, зникнення ознак запалення i епітелізація відбувалося швидше на 1-1,5доби. Повна епітелізація, залежно від площі та глибини ерозивновиразкових уражень, відбулася у хворих дослідної групи через 7-8 діб, а в пацієнтів групи порівняння - у терміни 8-9 діб.

\section{Висновки}

1. Препарат «Тантум Верде ${ }^{\circledR} \gg-$ ефективний місцевий знеболювальний засіб для тамування болю у хворих з ерозивно-виразковими ураженнями СОПР, що виникають після хронічної механічної травми зубними протезами та незнімними ортодонтичними апаратами. Він прискорює зникнення ознак запалення.

2. Медикаментозний супровід хірургічного видалення протезних гранульом із застосування «Тантум Верде ${ }^{\circledR} \gg$ ослаблює реактивну запальну реакцію тканин на хірургічне втручання, зменшує кількість інфікованого нальоту на післяопераційній ділянці, чим покращує гігієну, прискорює загоєння і зняття швів на 1-1,5 доби за рахунок протизапального, протинабрякового та протимікробного впливів.

3. Використання «Тантум Верде ${ }^{\circledR}$ » для лікування декубітальних ерозивно-виразкових уражень слизової оболонки губ та щік, спричинених брекетсистемами, після ізоляції їх від травмуючого чинника справляє заспокійливий ефект в рані, покращує трофіку, прискорює загоєння та епітелізацію дефектів.

\section{ПОСИЛАННЯ}

1. Batig VM, Lyesnuhina AL. Efektivnist kompleksnogo likuvannya generalizovanogo parodontita u hvorih z perevazhannyam simpatichnoyi nervovoyi sistemi z vikoristannyam Tantum Verde ${ }^{\circledast}$ u viddaleni stroki sposterezhen Suchasna stomatologiya. 2019 Cher 12; 96(2): 28-31. [In Ukrainian].

2. Borisenko AV, Batig VM, Ivanicka OV, Dimitrova AG. Tantum Verde ${ }^{\circledR}$ v kompleksni terapiyi generalizovanogo parodontitu u hvorih z perevazhannyam parasimpatichnoyi nervovoyi sistemi Suchasna stomatologiya. 2017 Cher; 86(2): 40-43. [In Ukrainian].

3. Godovanij OV, Godovana OI. Osoblivosti zastosuvannya rozchinu Tantum Verde ${ }^{\circledR} \mathrm{v}$ pidgotovci parodontologichnih hvorih do ortodontichnogo likuvannya. Suchasna stomatologiya. 2018 Zhov; 94(5): 44-48. [In Ukrainian].

4. Godovanij OV, Godovana Ol. Zastosuvannya preparativ Tantum Verde ${ }^{\circledR}$ u profilaktici ushkodzhen slizovoyi obolonki porozhnini rota pri zastosuvanni neznimnoyi ortodontichnoyi tehniki. Suchasna stomatologiya. 2019 Cher; 97(3): 68-71. [In Ukrainian].

5. Idashkina NG, Madzhdi Aliakbar. Shlyahi pokrashennya gigiyenichnih umov dlya hvorih z perelomami nizhnoyi shelepi. Suchasna stomatologiya. 2018 Trav; 91(2): 50-53. [In Ukrainian]

6. Instrukciya dlya medichnogo zastosuvannya preparatu Tantum Verde ${ }^{\circledast}$ (Tantum Verde ${ }^{\oplus}$ ). Nakaz MOZ vid 22.11.2010. [In Ukrainian].

7. Kazarina LN, Pursanova AE. Kliniko-immunologicheskaya ocenka effektivnosti primeneniya Polioksidoniya i Tantum Verde ${ }^{\circledR}$ pri lechenii kataralnogo ginigivita u detej S hronicheskim gastroduodenitom. Stomatologiya. 2014; (1): 43-45. [In Russian].

8. Klitinska OV. Tantum Verde ${ }^{\varpi}$ - preparat viboru pri kompleksnij terapiyi stomatologichnih zahvoryuvan. Suchasna stomatologiya. 2017 Ber; 85(1): 40-41. [In Ukrainian].

9. Moskalenko V.F. Socialna medicina i organizaciya ohoroni zdorov'ya. Kyiv: Kniga plyus; 2010. 328 p. [In Ukrainian].

10. Nesin A.F. Lechenie yazvenno-nekroticheskih porazhenij slizistoj obolochki polosti rta. PhD [thesis]. Kyiv; 1979. 24 p. [In Ukrainian].

11. Petrushanko TO, Popovich IYu. Efektivnist zastosuvannya Tantum Verde ${ }^{\circledR}$ na eta- pah profesijnoyi gigiyeni. Suchasna stomatologiya. 2018 Trav; 92(3): 28-30. [In Ukrainian].

12. Pechkovska IM, Nesin OF, Pechkovskij KYe, Viderska GV, Timohina TO. Vikoristannya Tantum Verde ${ }^{\circledR}$ na etapah kompleksnogo likuvannya hvorih na generalizovanij parodontit. Suchasna stomatologiya. 2019 Ber 14; 95(1): 26-29. [In Ukrainian].

13. Popovich IYu, Petrushanko TA. Miscevij medikamentoznij suprovid porozhnini rota paciyentiv pislya dentalnoyi implantaciyi. Suchasna stomatologiya. 2018 Zhov; 93(4): 80-82. [In Ukrainian]

14. Skripnikova TP, Loban GA, Stupak EP, Gancho OV. Primenenie Tantum Verde ${ }^{\circledR} v$ kompleksnoj terapii gribkovyh porazhenij slizistoj obolochki polosti rta. Suchasna stomatologiya. 2016 Trav; 81(2): 42-45. [In Ukrainian].

15. Strahova SYu, Drobotko LN. Primenenie preparata Tantum Verde ${ }^{\circledR}$ pri porazheniyah slizistoj obolochki polosti rta travmaticheskogo proishozhdeniya. Stomatolog praktik. 2012; (4): 46-48. [In Russian].

16. Timofeev AA, Timofeev AA, Ushko NA, Yarifa MA, Savickij AA. Profilaktika vospalitelnyh oslozhnenij posle udaleniya zubov mudrosti. Suchasna stomatologiya. 2016 Trav; 83(4): 24-31. [In Ukrainian].

17. Timofeev AA, Ushko NA. Profilaktika vospalitelnyh oslozhnenij posle udaleniya opuholej i opuholepodobnyh obrazovanij chelyustej. Suchasna stomatologiya. 2018 Ber; 90(1): 76-79. [In Ukrainian]

18. Fesenko El. Osobennosti diagnostiki, lecheniya i profilaktiki vospalitelnyh oslozhnenij u bolnyh $\mathrm{s}$ neognestrelnymi perelomami nizhnej chelyusti. PhD [dissertation]. Kyiv: NMAPO; 2016. 254 p. [In Ukrainian].

19. Chumakova YuG, Troyanenko LM, Golubkova NM. Ocinka efektivnosti preparatu "Tantum Verde ${ }^{\Theta}$ u k kompleksnomu likuvanni zahvoryuvan parodonta ta slizovoyi obolonki porozhnini rota. Sovremennaya stomatologiya. 2010; 42(3): 55-60. [In Ukrainian].

20. Cioli V, Corradino C, Scorza-Barcellona P. Review of pharmacological data on benzidamine. Int. J. Tissue React. - 1985. - V.7. - P. 205-213. 
21. Epstein JB. Benzydamine $\mathrm{HCl}$ in the prevention of oropharyngeal mucositis in radiation therapy: literature review and clinical study. In: Dick WC, Bowsher DR., editors. Benzydamine: a topical NSAID. Res. Clin. Forums - 1988. - V. 10. - P. 91-99.

22. Hunter KM. A clinical evaluation of benzydamine hydrochloride. Aust. Dent J. 1978. - V.23. - P. 164-166.

23. Riddington Young J. A camparative study of benzydamine hydrochloride and placebo as analgesics following tonsillectomy. Res. Clin. Forums. - 1988. - V. 10. P. 102-107.
24. Runti C, Baiocchi L. The chemistry of benzydamine. Int. J. Tissue React. - 1985. V. 7. - P. $175-186$.

25. Samaranayake LP, Robertson AG, MacFarlane TW, Hunter IP, MacFarlane G, Soutar DS et al. The effect of chlorhexidine and benzydamine mouthwashes on mucositis induced by therapeutic irradiation. Clin. Radiol. - 1988. - V. 39. - P. 291-294.

26. White SK. The pharmacology of benzydamine. Res. Clin. Forums. - 1988. V. 10. - P. $21-25$.

\title{
Использование Тантум Верде® в лечении хронической механической травмы слизистой оболочки полости рта
}

\author{
К.Е. Печковский, А.Ф. Несин, И.М. Печковская, Т.А. Тимохина , А.Г. Шкредъ
}

Актуальность. В лечении эрозивно-язвенных поражений слизистой оболочки полости рта, вызванных хронической механической травмой, обосновано применение средств комплексного действия, обладающих местными противовоспалительными, обезболивающими, антисептическими и противомикробными свойствами. Один из них - Тантум Верде ${ }^{\circledR}$ - местный нестероидный противовоспалительный препарат на основе бензидамина гидрохлорида. Целью работы была оценка эффективности использования препарата «Тантум Верде ${ }^{\circledR}$ в местном лечении эрозивно-язвенных поражений слизистой оболочки полости рта, обусловленных хронической механической травмой.

Результаты исследований. Проведено лечение 30 больных в возрасте 18-58 лет, с эрозивно-язвенными поражениями слизистой оболочки полости рта, вызванными хронической механической травмой ортопедическими конструкциями или ортодонтическими аппаратами. У 6 пациентов со съемными протезами отмечали также разрастание слизистой оболочки в участках контакта с краями протеза. У 15 больных опытной группы был дополнительно применен препарат «Тантум Верде ${ }^{{ }}$.

Исчезновение или значительное уменьшение клинических признаков эрозивно-язвенных поражений от механической травмы ортопедическими конструкциями или ортодонтическими аппаратами произошло на 1-1,5 сутки раньше у больных опытной группы. Отмечено положительное влияние Тантум Верде ${ }^{\circledR}$ на снижение боли, гигиеническое состояние, улучшение трофики тканей и заживление участков слизистой оболочки после хирургического удаления протезных гранулем.

Выводы. Препарат «Тантум Верде ${ }^{\circledast_{»}}$ эффективно обезболивает и ускоряет исчезновение признаков воспаления, улучшает трофику, ускоряет заживление и эпителизацию дефектов у больных с эрозивно-язвенными поражениями слизистой оболочки полости рта, возникающих после хронической механической травмы зубными протезами и несъемными ортодонтическими аппаратами. Он ослабляет реактивную воспалительную реакцию тканей на хирургическое вмешательство после удаления протезных гранулем, улучшает гигиену, ускоряет заживление и снятие швов на 1-1,5 сутки.

Ключевые слова: «Тантум Верде ${ }^{{ }}$, хроническая механическая травма слизистой оболочки полости рта, эрозивно-язвенные поражения, местное лечение.

\section{The use of Tantum Verde ${ }^{\circledast}$ in the treatment of chronic mechanical trauma} of oral mucous membrane

\section{K. Pechkorskiy, O. Nesin, I. Pechkovska, T. Timokhina, O. Shkred'}

Actuality. In the treatment of erosive-ulcerative lesions of oral mucous membrane, caused by chronic mechanical trauma, it is reasonable to use the agents of complex action which would produce a local anti-inflammatory effect and reduce mucosal pain, and would have antiseptic and antimicrobial properties. One of them is Tantum Verde ${ }^{\circledR}$, a local non-steroidal drug based on benzidamine hydrochloride.

The aim of the research was to evaluate the effectiveness of the use of the preparation «Tantum Verde ${ }^{\Theta}$ » in the local treatment of erosive-ulcerative lesions of the oral mucous membrane caused by chronic mechanical trauma.

Results of the research. There were treated 30 patients aged 18-58 with erosive-ulcerative lesions of oral mucous membrane, caused by chronic mechanical trauma of orthopedic structures or orthodontic devices. It was noted that 6 patients with removable prostheses had the growth of mucous membrane in areas of contact with the edges of the prosthesis. Among 15 patients from the experimental group, the preparation «Tantum Verde ${ }^{\Theta}$ ) was additionally used.

Absence or significant reduction of clinical signs of erosive-ulcerative lesions caused by mechanical trauma of orthopedic structures or orthodontic devices occurred $1-1,5$ days earlier among the patients of experimental group. It is noted the positive effect of Tantum Verde ${ }^{\circledR}$ on pain reduction, hygienic condition, improvement of tissue trofics and healing of mucous membrane areas after surgical removal of prosthetic granulomas.

Conclusions. The preparation «Tantum Verde ${ }^{\circledR}$ » is an effective painkiller that accelerates the disappearance of inflammatory signs, improves trophics, accelerates healing and epithelization of defects at patients with erosive-ulcerative lesions of oral mucous membrane, caused by chronic mechanical trauma with dental prostheses and non-removable orthodontic devices. It weakens the reactive inflammatory reaction of tissues to surgery after prosthetic granulomas removal, improves hygiene, accelerates healing and suture removal for 1-1,5 days.

Keywords: «Tantum Verde ${ }^{\circledR}$, chronic mechanical trauma of oral mucous membrane, erosive-ulcerative lesions, local treatment.

Печковсъкий Костянтин Євгенович - канд. мед. наук, асистент кафедри терапевтичної стоматологї НМУ ім. О.О. Богомольия. Тел.: (050) 411-28-20. E-mail: konpech@i.ua;

Несин Олександр Федорович - канд. мед. наук, доцент кафедри терапевтичної стоматологї НМУ ім. О.О. Богомольия.

тел.: (096) 517-11-33;

Печковська Ірина Михайлівна - канд. мед. наук, доцент кафедри ортопедичної стоматологї та ортодонтї

Приватного вищого навчального закладу «Киівський медичний університет».

Тімохіна Тетяна Олександрівна - канд. мед. наук, доцент кафедри терапевтичної стоматологї НМУ ім. О.О. Богомольия.

Шкредь Олександр Григорович - асистент кафедри терапевтичної стоматологї НМУ ім. О.О. Богомольия. 